УдК : 330.34.011

\title{
ІНДЕТЕРМІНІЗМ Й СПОВІЛЬНЕННЯ ЗРОСТАННЯ СВІТОВОЇ ЕКОНОМІКИ ТА ЇХНІ НАСЛІДКИ ДЛЯ ГЛОБАЛЬНОГО РОЗВИТКУ НА СУЧАСНОМУ ЕТАПІ
}

\section{Ревенко Анатолій Дмитрович}

Надіслано:

10.10.2020

кандидат економічних наук, доцент,

Київський університет культури,

Рецензовано:

26.10 .2020

м. Київ, Україна

ORCID: 0000-0002-4555-0677

Прийнято:

revenkoad@ukr.net

06.11 .2020

Метою дослідження $є$ аналіз сповільнення зростання та індетермінізму (невизначеності) у межах світової економіки, з'ясування їх наслідків для глобального розвитку, що обумовлює розгляд міжнародних економічних тенденцій, дискусій навколо ситуації з міжнародною торгівлею та відновлення фінансової нестабільності. Методологія дослідження грунтується на загальнонаукових методах, а також спеціалізованих методах економічного аналізу. Аргументація теоретичних положень і висновків здійснена на основі системного підходу 3 використанням методів історико-логічного, структурнофункціонального та компаративного аналізу. Обгрунтовується теза про те, що у 2015 р. ООН запустила три основні глобальні програми (Цілі сталого розвитку, Аддис-Абебська програма дій та Паризька кліматична угода), які станом на сьогодні зіштовхнулася з послабленням мультилатеральності, дестабілізацією та масштабними невизначеностями, що оточують світову економіку, до яких відтепер додалися наслідки пандемії COVID-19 для здоров'я, економіки та соціальної діяльності. Доведено, що очікуване сповільнення темпів зростання світової економіки погіршилося через пандемію, яка спричинила найгіршу економічну кризу з часів Великої депресії. Хоча наслідки, зумовлені COVID-19 на фінансових ринках, пом'якшувалися масовим втручанням центральних банків розвинених країн, глобальна співпраця в цій галузі була набагато слабшою, ніж після північно-атлантичної фінансової кризи. Зроблено висновок: щоб змінити та обернути у зворотному напрямку ці масові несприятливі тенденції, система $\mathrm{OOH}$ повинна постати форумом для великих політичних домовленостей, які мають важливе значення для досягнення амбіційних планів розвитку, погоджених у 2015 р. Запропоновано рекомендації: по-перше, розроблення більш посилених механізмів співпраці 3 країнами, що розвиваються, не лише у сфері охорони здоров'я, а й для управління негативними соціально- 
економічними наслідками кризи COVID-19; по-друге, оновлення зобов'язань щодо зміцнення торговельної мультилатеральності та подолання поточного колапсу міжнародної торгівлі; по-третє, порядок денний для глобального валютно-фінансового співробітництва, не менш амбітний ніж той, що був прийнятий після північноатлантичної фінансової кризи.

Ключові слова: світова економіка; глобальний розвиток; COVID-19; сповільнення; індетермінізм; міжнародна торгівля; фінансові ринки.

Revenko Anatolii, Candidate of Economic Sciences, Associate Professor, Kyiv University of Culture, Kyiv, Ukraine

Indeterminism and Slowdown of the World Economy Growth and Their Consequences for the Global Development on the Contemporary Stage

The aim of the investigation is the analysis of growth slowdown and indeterminism (uncertainty) in the measures of the world economy, consequences clarification for the global development, which stipulates the consideration of the international economical tendencies, discussions around the situation with the international trade and restoration of the financial instability. Methodology of the research is based on the general scientific methods and on specialized methods of the economic analysis. Argumentation of theoretical positions and conclusions is done on the system approach basis with using the following methods: historical-logical, structural-functional and comparative analysis. The thesis that in 2015 UN run three main global programs (Purposes of constant development, Addis Ababa program and Paris climate agreement) is substantiated which as of today have faced a weakening of multilateralism, destabilization and large-scale uncertainties surrounding the world economy, to which the effects of the COVID-19 pandemic on health, the economy and social activities are now added. It is proved that that the expected slowdown in the world economy has been exacerbated by the pandemic that has caused the worst economic crisis since the Great Depression. Although the effects of COVID-19 on financial markets were mitigated by massive intervention by central banks in developed countries, global cooperation in this area was much weaker than after the North Atlantic financial crisis. It is concluded: to change and turn in the opposite direction these mass tendencies, the UN system must become the forum for the great political agreement, having the important meaning for reach these ambition development plans agreed in 2015. It was recommended: firstly, to develop more enhanced mechanisms for cooperation with developing countries, not only in the field of health, but also to manage the negative socio-economic consequences of the COVID-19 crisis; secondly, re-new commitments to strengthen trade multilateralism and overcome the current collapse of international trade; thirdly, the agenda for global monetary and financial cooperation is no less ambitious than the one adopted after the North Atlantic financial crisis. 
Key words: world economy; global development; COVID-19; slowdown; indeterminism; international trade; financial markets.

Ревенко Анатолий Дмитриевич, кандидат экономических наук, доцент, Киевский университет культуры, г. Киев, Украина

Индетерминизм и замедление роста мировой экономики и их последствия для глобального развития на современном этапе

Целью исследования является анализ замедления роста и индетерминизма (неопределенности) в рамках мировой экономики, выяснения их последствий для глобального развития, что обусловливает рассмотрение международных экономических тенденций, дискуссий вокруг ситуации с международной торговлей и восстановления финансовой нестабильности. Методология исследования основана на общих научных методах, а также специализированных методах экономического анализа. Аргументация теоретических положений и выводов осуществлена на основе системного подхода с использованием методов историко-логического, структурнофункционального и сравнительного анализа. Обосновывается тезис о том, что в 2015 г. ООН запустила три основные глобальные программы (Цели устойчивого развития, Аддис-Абебськая программа действий и Парижское климатическое соглашение), которые на сегодня столкнулась с ослаблением мультилатеральности, дестабилизацией и масштабными неопределенностями, что окружают мировую экономику, к которым отныне добавились последствия пандемии COVID-19 для здоровья, экономики и социальной деятельности. Доказано, что ожидаемое замедление темпов роста мировой экономики ухудшилось из-за пандемии, которая стала причиной худшего экономического кризиса со времен Великой депрессии. Хотя последствия, вызванные COVID-19 на финансовых рынках, смягчались благодаря массовым вмешательствам центральных банков развитых стран, глобальное сотрудничество в этой области стало намного слабее, чем после североатлантического финансового кризиса. Сделан вывод: чтобы изменить и обратить эти массовые неблагоприятные тенденции, система ООН должна стать форумом для крупных политических договоренностей, которые имеют важное значение для достижения амбициозных планов развития, согласованных в 2015 г. Предложены рекомендации: во-первых, разработка более усиленных механизмов сотрудничества с развивающимися странами не только в сфере здравоохранения, но и для управления негативными социальноэкономическими последствиями кризиса COVID-19; во-вторых, обновление обязательств по укреплению торговой мультилатеральности и преодолению текущего коллапса международной торговли; в-третьих, повестка дня для глобального валютно-финансового сотрудничества должна быть не менее 
амбициозной, чем та, которая была принята после североатлантического финансового кризиса.

Ключевые слова: мировая экономика; глобальное развитие; COVID-19; замедление; индетерминизм; международная торговля; финансовые рынки.

\section{Вступ}

В останні роки відбуваються суттєві зміни в реалізації глобального порядку денного, пов'язані з дестабілізацією світового економічного контексту. Спочатку важливо відзначити позитивні аспекти, під якими необхідно розуміти домовленості, досягнуті ООН у 2015 р.: затвердження Цілей сталого розвитку, Третя міжнародна конференція 3 фінансування розвитку в Аддис-Абебі та Паризька кліматична угода. На жаль, остання вже заплямоване рішенням США залишити Угоду та відмовою на пізнішій зустрічі в Мадриді досягти консенсусу щодо функціонування світового вуглецевого ринку. Позитивним $\epsilon$ те, що програма міжнародного податкового співробітництва, яку G20 доручила ОЕСР, продовжує рухатися вперед, хоча і з деякими реверсивними моментами. Зміни у фінансовому регулюванні, ініційовані G20 після північноатлантичної фінансової кризи 2008-2009 рр., також тривають, хоч і 3 певними змінами в деяких розвинених країнах.

Негативним та найбільш тривожним моментом можна вважати кризу мультилатералізму, пов'язану значною мірою з рішеннями США, які свого часу були великим рушієм багатостороннього співробітництва після Другої світової війни. Цьому сприяло також послаблення Європейського Союзу (ЄС). Серед основних наслідків цієї кризи виявилися погіршення інституційної структури міжнародної торгівлі в результаті так званої торгової війни між Китаєм та США, різні односторонні дії США спільно з іншими партнерами та призупинення дії Апеляційного органу Світової організації торгівлі (СОТ). Крім того, все це відбувається в умовах повільного зростання темпів світової торгівлі з часів північноатлантичної фінансової кризи. Світова економіка вже переживала істотний спад, перш ніж у 2020 р. ̈ㅣ спіткав найгірший колапс з часів Великої депресії 1930-х рр. та значне зменшення обсягів міжнародної торгівлі через наслідки пандемії COVID-19. Важливо, що нова економічна невизначеність відобразилася на світових ринках капіталу загалом і на міжнародних фінансових ринках, особливо, на новій волатильності потоків капіталу до країн, що розвиваються. До цього можна додати недоліки та послаблення домовленостей щодо кліматичних змін.

\section{Аналіз останніх досліджень і публікацій}

Суттєвим джерелом аналізу сповільнення зростання та індетермінізму (невизначеності) у межах світової економіки, з'ясування їх наслідків для 
глобального розвитку є праці Дж. Вакха та С. Лестера, Л. Бертоли та Х. А. Окампо, К. Діао, М. Макміллан та Д. Родріка, Ч. Кіндлебергера та ін., а також матеріали Міжнародного валютного фонду, Світового банку та Світової організації торгівлі.

\section{Формулювання цілей статті}

Метою статті $\epsilon$ аналіз дестабілізаційних процесів й індетермінізму (невизначеності) у межах світової економіки, з'ясування їх наслідків для глобального розвитку, що передбачає розгляд міжнародних економічних тенденцій, дискусій навколо ситуації з міжнародною торгівлею та відновлення фінансової нестабільності.

\section{Виклад основного матеріалу дослідження}

До того, як пандемія COVID-19 завдала удару по світовій економіці, міжнародні дискусії зосереджувалися в основному на «синхронізованому уповільненні» світової економіки, що помітно за світовими економічними прогнозами Міжнародного валютного фонду за жовтень 2019 р. (International Monetary Fund, 2019). Використовуючи вихідні дані ООН аналізу для світової економічної ситуації, які розраховується за ринковими курсами, а не за паритетними цінами, як у МВФ, беручи до уваги погіршення економічних наслідків через COVID-19, важливо відзначити, що у 2019 р. світова економіка пережила найповільніше зростання (2,3 \%) з часу відновлення, яке відбулося після північноатлантичної фінансової кризи. Це правильно порівняно з піком у 2017 р. (3,2 \%) та з середнім показником 2010-2018 рр. (2,8 \%). Особливо це стосується розвинених економік, зокрема Японії та ЄС. Уповільнення відбулося також у США і продовжилося у 2020 р. Крім того, воно супроводжувало загальносвітові темпи зростання, які не досягли п'ятирічного рівня до кризи 2008-2009 pp. (3,9\% у 2002-2007 pp.), а також тих, що були досягнуті у 1990-2007 pp. (3,0\%). Іншими словами, відбулося незначне зростання в контексті тенденції до уповільнення, яка у довгостроковій перспективі розпочалася у 1970-х чи 1980-х рр. у різних частинах розвиненого світу.

Ці несприятливі тенденції поступилися місцем найгіршій з часів Великої депресії економічній кризі у 2020 р., коли МВФ спрогнозував широкомасштабну рецесію, яка призведе до падіння світового ВВП на 4,2 \% (за ринковими курсами), зі зміщенням у бік зниження та значною невизначеністю швидкості відновлення (International Monetary Fund, 2020a).

Розвинені країни відреагували на поточну кризу рішучою експансивною монетарною та фіскальною політикою, яка особливо жорстка у випадку США. Неортодоксальна монетарна політика змогла пом'якшити несприятливі тенденції на фінансових ринках, але незрозуміло, чи допоможе ця політика разом із амбіційною фіскальною політикою, яка зосереджується на вимірах попиту в умовах кризи - подолати обмеження пропозиції, породжені COVID-19. Одним із наслідків поточної політики стане значне збільшення коефіцієнтів 
боргу в державному секторі на додачу до сильних негативних тенденцій в останні роки, особливо в США.

Економіки країн, що розвиваються, також зазнали уповільнення до кризи COVID-19 і зараз прямують до широкомасштабної рецесії. Це охопило й більш динамічні регіони, Південно-Східну Азію, включаючи дві найбільші економіки, Китай та Індію, які є одними з небагатьох, що зможуть продемонструвати повільне позитивне зростання у 2020 р. Однак Китаю не вдалося прийняти пакет фіскальних та кредитних експансій, аналогічний масштабному, активованому у відповідь на північноатлантичну фінансову кризу, особливо 3 огляду на високий рівень заборгованості, який створив цей пакет. Високий фіскальний дисбаланс в Індії також є основним обмеженням для прийняття суворішої експансіоністської політики.

Латинська Америка та Карибський басейн $\epsilon$ найменш динамічним регіоном у країнах, що розвиваються, але це відображає тенденцію, що мала місце після боргової кризи 1980-х рр. Його недостатня ефективність обумовлена не лише міжнародними подіями, але й внутрішніми та регіональними факторами, як економічними, так i політичними. Сюди входить крах венесуельської економіки, що розпочався у 2014 р., повільне відновлення Бразилії від найсильнішої післявоєнної рецесії у 2015-2016рр., політичні перетворення в Аргентині та Мексиці, а також політичні негаразди в Чилі та ряді інших країн. COVID-19 сильно вдарив по регіону, зупинивши відновлення, яке очікувалося в 2020 р.

В останні роки сповільнення зростання економіки було характерною рисою країн Африки на південь від Сахари, що спричинило розчарування у тому, що цей регіон нарешті подолав історичну розбіжність у рівнях доходів 3 розвиненими країнами. Були й деякі позитивні новини для країн, що розвиваються: найменш розвинені країни - особливо в Азії - не тільки пережили бум на поч. XXI ст., але й мали показники вище середнього за останні роки.

Деякі довгострокові несприятливі тенденції, безсумнівно, мали значний вплив на найслабші регіони країн, що розвиваються: Африку, Латинську Америку та Карибський басейн. Хотілося б виділити дві такі тенденції, які тісно взаємопов'язані: по-перше, обмежені структурні зміни в ході перерозподілу робочої сили на сектори 3 високим рівнем продуктивності праці, що визначається як важливий елемент зменшення розриву в доходах між розвиненими країнами та тими, що розвиваються; по-друге, низький рівень інвестицій у дослідження та розробки, що особливо важливо для переходу від середнього рівня доходу до високого рівня.

Аналізуючи перших з цих питань, С. Діао, М. Макміллан та Д. Родрік (Diao, McMillan and Rodrik, 2019) вважають, що зростання у всіх регіонах країн, 
що розвиваються, прискорилося особливо на поч. XXI ст., і цей процес продовжився в деяких з них навіть після північноатлантичної фінансової кризи, коли в ряді випадків був підтриманий суперцикл цін на товари у 2003-2014 рр. за умови тимчасового призупинення під час зазначеної кризи. Однак структурні зміни за останні десятиліття були особливо слабкими в ряді регіонів. Зокрема, на відміну від східноазіатського досвіду, прискорення зростання в Африці, Латинській Америці та Південній Азії не було зумовлене швидкою індустріалізацією.

Як стверджують автори, нечасто можна спостерігати зміни в економічній структурі, завдяки яким робоча сила переходить з рангу низькопродуктивної до високопродуктивної разом зі швидким підвищенням продуктивності в секторі синтез, що обумовив швидке зростання в Східній Азії та ліг в основу класичного розвитку економічного мислення. Таким чином, Африка отримала користь від першої з цих трансформацій, але не від другої (тобто вона мала зниження продуктивності праці в сучасних секторах економіки), а ось Латинська Америка пережила другу, але не першу. Дослідники пояснюють африканську аномалію аргументацією того, що структурні зміни в Африці виникли на стороні попиту в результаті або зовнішніх трансфертів, або збільшення доходів від сільського господарства. У свою чергу, як визнавали Л. Бертола та Х. А. Окампо (Bértola, and Ocampo, 2012), спільний ефект боргової кризи 1980-х pp. із передчасною деіндустріалізацією, яку пережив цей регіон після ринкових реформ 1990-х рр., призвів до дуже низьких показників порівняно 3 епохою післявоєнної індустріалізації: середній приріст ВВП лише 1990 р. становив 2,7 \% на рік проти 5,5 \% у 1950-1980 рр. Це повільне зростання зумовило стагнацію регіону на середньому рівні доходів та є яскравим прикладом того, що в сучасній економічній літературі прийнято називати «пасткою середнього рівня доходу» («middle-income trap»). Слід також пам'ятати, що Латинська Америка та Африка на південь від Сахари залишаються регіонами з найвищим рівнем нерівності у світі, незважаючи на покращення на початку нинішнє століття. На думку аналітиків, нерівність також може бути фактором слабких економічних показників.

Різниця у витратах на R\&D (науково-дослідні та дослідноконструкторські роботи) $є$ основним джерелом відмінностей між розвиненими країнами та країнами, що розвиваються. Різниця зменшилася на поч. XXI ст., але це пов'язано головним чином із зростанням витрат на R\&D у Cхідній Азії і особливо в Китаї з 0,9 \% ВВП у 2000 р. до 2,1 \% у 2016 р. Незначний прогрес відбувся в інших регіонах країн, що розвиваються, а також в рамках перехідних економік, які домінують у Центральній та Східній Європі та Центральній Азії. Значне відставання Індії від Китаю є показовим у цьому плані. В епоху стрімкого технологічного розвитку - «четвертої промислової революції», як їі називали, 
ця відсталість $\epsilon$ непродуктивною та однією з найважливіших причин нерівності в рівнях розвитку, особливо враховуючи ситуацію 3 «middle-income trap» у кількох країнах.

Одним із найпоширеніших дорікань на адресу перспективних тенденцій індустріалізації у кількох регіонах країн, що розвиваються, у повоєнний період був надмірний захист вітчизняного виробництва, що призвів до неефективності, i, як наслідок, неспроможності інтегруватися в рамки динамічного зростання міжнародної торгівлі. Отже, основним аргументом на захист лібералізації торгівлі було те, що це важливо з метою отримання вигоди від буму міжнародної торгівлі, який розпочався відносно рано в післявоєнний період. Слід зазначити, однак, що цей бум переважно був зосереджений на початкових етапах торгівлі серед розвинених країн, де внутрішньо європейська торгівля найважливіша, і лише починаючи з середини 1960-х рр. почав надавати можливості країнам, що розвиваються. Витоки східноазіатської історії успіху, як і Китаю, пов'язані 3 повним використанням цих можливостей, хоча це, як правило, передбачало поєднання хороших експортних секторів із постійною підтримкою вітчизняних галузей та загалом високим рівнем державного втручання

Повоєнний торговий бум був зупинений першим нафтовим шоком наприкінці 1973 р. Сповільнення тривало поки ціни на нафту залишалися високими. Починаючи з 1986 р., відбувся другий підйом міжнародної торгівлі. Попри те, що зростання світового ВВП ніколи не досягало темпів післявоєнного буму, торговельні показники між 1986 та 2007 рр. все ж досягли схожих темпів понад 7 \%. Більше того, другий підйом позначився набагато активнішою участю країн, що розвиваються, серед іншого завдяки міжнародним ланцюгам створення вартості. Попри те, що лібералізація торгівлі була головною рисою першого буму, в основному вона зосереджувалася на зниженні тарифів серед розвинених країн у відповідності до послідовності переговорів за Генеральною угодою з тарифів і торгівлі (General Agreement on Tariffs and Trade (GATT)). Ця лібералізація була масштабнішою та сприяла другому буму, адже включала країни, що розвиваються, і відбувалася в рамках СОТ, а також буму двосторонніх та багатосторонніх угод про вільну торгівлю.

Другий підйом міжнародної торгівлі закінчився Північноатлантичною фінансовою кризою - факт, який часто ігнорується. Дійсно, розвиток міжнародної торгівлі з 2007 р. був найповільнішим у повоєнний період. Різке зниження темпів зростання торгівлі також перевершило сповільнення зростання світового ВВП. Під час найгострішої фази північноатлантичної фінансової кризи відбулося різке падіння, але також було й швидке відновлення, коли торгівля відновилася до докризового рівня наприкінці 2010 р.

У цьому сенсі важливі скоординовані дії G20 з метою уникнення протекціоністських заходів під час кризи. Справді, Велика депресія 1930-х рр. 
була взята за зразок, коли широкий протекціонізм загострив глибоку кризу, яку переживала світова економіка того часу. Однак відновлення не призвело до нового періоду швидкого розширення: темпи щорічного реального приросту торгівлі становили 2,0 \% на рік у 2007-2019 pp. і 2,2\% у 2011-2019 рр., що нижче оцінок МВФ. Починаючи з кінця 2019 р. ці показники почали знижуватися; дійсно, з точки зору вартості, глобальна торгівля в 2019 р. була не набагато вищою, ніж у 2011 р., або навіть у 2007 р.

Нині у торговій політиці існує велика невизначеність. 3 точки зору багатосторонньої системи, найбільша загроза - призупинення дії Апеляційного органу СОТ 11 грудня 2019 р. через відсутність призначення нових членів. Витоки цієї загрози сягають заперечень проти Апеляційного органу з боку США, особливо із твердженням, що рішення використовуються як «прецеденти»звинувачення, які навіть американські експерти вважають необгрунтованими (Bacchus and Lester, 2019). Інші заперечення стосуються думок, які Апеляційний орган висловив щодо використання контингентних засобів захисту, зокрема антидемпінгових заходів США. Ці заперечення пролунали, незважаючи на те, що Америка використала на свою користь рішення Органу (наприклад, рішеннями на користь США щодо європейських субсидій Airbus).

Незважаючи на те, що переговори щодо врегулювання суперечок у рамках СОТ тривають і пропонуються тимчасові механізми, США протягом останніх двох років відхиляли пропозиції, представлені європейськими та іншими країнами. Тому світ ризикує втратити найкращий інструмент врегулювання суперечок у межах багатосторонньої системи, вирішальний для гарантування дотримання країнами правил СОТ. У системі суперечки вирішувалися у строгій та обмеженій строком послідовності: (i) консультації між залученими сторонами, (ii) посередництво та (iii) можливий арбітраж апеляційного органу. Арбітражні рішення також повинні виконуватися, інакше постраждала сторона буде піддаватися переслідуванню у судовому порядку. Цей механізм врегулювання суперечок використовувався великою кількістю розвинених країн та тих, що розвиваються.

Окрім кризи СОТ, інша складна проблема, що стоїть перед міжнародною торгівлею, це одностороннє використання торгових заходів США, навіть у випадках, не пов'язаних безпосередньо з торгівлею (як це сталося з Мексикою для стримування нелегальної імміграції), або досягнення геополітичних цілей. (санкції для компаній, що торгують з Боліваріанською Республікою Венесуела або Ісламською Республікою Іран). Показовий випадок - торгова війна з Китаєм, яка переслідує частково законні цілі (наприклад, припинення можливих порушень правил інтелектуальної власності з боку Китаю), порівняно з іншими, які не мають чіткого економічного обгрунтування (наприклад, зменшення дефіциту двосторонньої торгівлі), або які передбачають використання інших 
інструментів без чіткого обгрунтування (наприклад, маніпуляції з валютою Китаю, які, як вважають, робляться для утримання їі на низьких позиціях). Хоча тимчасове перемир'я було досягнуто в грудні 2019 р., ще належить з'ясувати, чи є це кроком до остаточного вирішення проблеми. Деякі заходи також суперечать міжнародним правилам торгівлі, зокрема наполяганню США на тому, щоб Китай взяв на себе зобов'язання здійснювати двосторонні закупівлі американських сільськогосподарських товарів, не враховуючи ринкові механізми.

Торгівельна війна сприяла сповільненню світової торгівлі, вплинувши на обидві країни негативно та перетворившись на один із ключових факторів, який найбільше сприяв дестабілізації світової економіки. Можна вказати й на інші наслідки, особливо у сфері інформаційних технологій, оскільки через санкції проти китайської компанії «Huawei», можуть виникнути дві паралельні системи цифрових технологій, скажімо, західна та китайська, які не взаємодіють між собою. Варто зазначити, що торговельна війна породила численні та неефективні торгові відхилення, деякі з яких були позитивними для окремих країн, що розвиваються (наприклад, експорт промислової продукції з Мексики до США, сої й кукурудзи з Аргентини та Бразилії до Китаю), а деякі негативними (наприклад, ймовірний демпінг деяких китайських виробів у тих країнах, які не мають обмежень на імпорт з боку азіатського гіганта).

Криза COVID-19, у свою чергу, призвела до значного скорочення обсягів міжнародної торгівлі, що спричинило зриви в ланцюгах створення вартості, а також падіння попиту на виробництво, проблеми з промисловим постачанням під час блокування в різних місцях, та додаткові проблеми, пов'язані 3 перебоями в роботі міжнародних транспортних та митних служб. У сфері обслуговування найбільше втратили авіакомпанії та туризм. За оцінками СОT, обсяг світової торгівлі у 2020 р. зменшиться між 13 і 32 \% (World Trade Organization, 2020). Порушення ланцюгів створення вартості може бути постійним, а тому відновлення, швидше за все, буде набагато слабшим, ніж після північноатлантичної фінансової кризи, або навіть неповним. У свою чергу, деякі ціни на сировину впали, зокрема енергоносії (особливо нафта) i, менше на кольорові метали, тоді як для сільськогосподарських товарів ситуація $\epsilon$ неоднозначною (World Bank, 2020). Це означає, що у питанні вартості падіння світової торгівлі буде набагато сильнішим.

Разом з тим, варто відзначити й позитивні зрушення у міжнародній торгівлі в останні роки, серед яких відновлене Транстихоокеанське партнерство попри вихід США з угоди. До цього можна додати угоду в листопаді 2019 р. між 15 азіатськими країнами про створення Регіонального всебічного економічного партнерства (Regional Comprehensive Economic Partnership), яке обіцяє стати найбільшою зоною вільної торгівлі у світі і яке буде ратифіковано в 2020 р. 
До цього списку слід додати підписання угоди про стратегічне партнерство між MERCOSUR та ЄC у червні 2019 р. Однак ця угода все ще очікує на ратифікацію через, по-перше, напружені суперечки між Бразилією та Францією з огляду на відсутність у Бразилії захисту Амазонських лісів; по-друге, через можливе заперечення 3 боку інших європейських країн; по-третє, беручи до уваги напруженість, яка може виникнути в MERCOSUR між новим урядом Аргентини та Бразилією.

Захист мультилатеральної торгівлі - зокрема захист врегулювання суперечок у рамках СОТ, включаючи Апеляційний орган - та рішуча відмова від використання односторонніх торгових заходів повинні бути частиною глобального порядку денного. У порядку денному СОТ також $\epsilon$ кілька невирішених питань, які необхідно розглянути, зокрема, що стосуються впливу нових технологій на торгівлю та взаємозв'язку між торговими та екологічними програмами. Порядок денний також повинен включати, звичайно, дотримання міжнародних угод Китаєм та США. У випадку Китаю зобов'язання щодо інтелектуальної власності $€$ критично важливими, хоча в цьому відношенні варто було б переглянути деякі норми, які обтяжують країни, що розвиваються.

На рахунок фінансової нестабільності та мінливості, то, як стверджує Ж. А. Окампо, невизначеність як така притаманна фінансам в цілому (Осатро, 2017). Цикли буму спаду зовнішнього фінансування в країнах, що розвиваються, $\epsilon$ відображенням того факту, що деякі з них призводять до глибокої фінансової кризи (Reinhart and Rogoff, 2009; Kindleberger, 2011). Цикли мають кілька спільних моментів у різних країнах, однак їхня інтенсивність залежить від ступеня відкритості різних країн для міжнародних потоків капіталу, а під час кризового періоду інтенсивність та тривалість «раптової зупинки» («sudden stop») фінансування залежать від того, як міжнародні фінансові ринки сприймають ризики. У деяких випадках ці цикли збігаються з більш вагомими світовими фінансовими подіями.

Починаючи з 1970-х рр., економіки, що розвиваються, пережили чотири цикли зростання й падіння зовнішнього фінансування, до яких тепер слід додати поточні негаразди від COVID-19. Першим був бум синдикованого банківського кредитування у другій половині 1970-х рр., посилений переробкою нафтодоларів, згодом, борговою кризою 1980-х рр. у Латинській Америці та деяких інших економіках, що розвиваються. Другий розпочався на поч. 1990-х рр., і основним його джерелом був міжнародний ринок облігацій; це збіглося в часі з бумом прямих іноземних інвестицій, які з тих пір стали більш стабільною формою фінансування для країн, що розвиваються. Він був перерваний кризою в декількох країнах Східної Азії у 1997 р. Третій цикл був частиною світового фінансового буму 2003-2007 pр., який включав значні потоки на внутрішні ринкі облігацій та фондові ринки економік, 
що формуються. Призупинений північноатлантичною фінансовою кризою, але на відміну від попередніх двох періодів був відносно коротким, значною мірою через сильно експансивну монетарну політику, прийняту центральними банками великих розвинених країн.

Четвертий бум розпочався у 2010 р., і це простежується за потоками портфельних інвестицій до економік, що розвиваються, які були спрямовані головним чином на внутрішні ринки облігацій, а вже потім на акції. Цікаво відзначити, що криза єврозони 2011-2012 рр. мала обмежений вплив на ці потоки. Те саме можна сказати про перехід Федеральної резервної системи США до менш експансивної монетарної політики у 2013 р. Вплив великого відтоку капіталу Китаю у другій половині 2015 р. та на початку 2016 р. мав більш широкі наслідки, а також фінансова хиткість потоків до країн 3 економікою, що формується, у 2018-2019 рр. Ця мінливість значно вплинула на основні економіки, що розвиваються, серед інших на Аргентину, Бразилію, Російську Федерацію та Туреччину. Напади на окремі економіки були різноманітними, і багато країн продовжували користуватися хорошим доступом до зовнішнього фінансування.

Слід зазначити, що ці цикли також знайшли своє відображення в еволюції норм ризику та прибутковості облігацій країн з економікою, що розвивається. Найбільш різке збільшення рівня ризику відбулося під час кризи кін. XX - поч. XXI ст., особливо з моменту введення російського мораторію в серпні 1998 р. У свою чергу, найбільш різкий спад розподілу ризику відбувся під час буму 2003-2007 pp. Починаючи з 2010 р., межі ризику коливалися, але в більш помірному діапазоні межах, ніж це було в минулому, за винятком найбільш постраждалих економік.

Криза COVID-19 також спричинила глобальні фінансові зриви, але завдяки масовому втручанню центральних банків розвинених країн (зокрема ФРС) вдалося пом'якшити фінансовий колапс і фактично частково відновити фінансові ринки (International Monetary Fund, 2020b). Вона спочатку генерувала найгірший відтік портфельного капіталу з країн, що розвиваються, в історії, але на ринках облігацій цих країн почали спостерігатися ознаки відновлення з середини квітня 2020 p. (International Monetary Fund, 2020b). Проте залишаються чимало невизначеностей, які пов'язані зі страхом, що відновлення після краху економічної діяльності може зіткнутися з серйозними невдачами.

Для усунення цієї нестабільності у 2012 р. МВФ прийняв «інституційний погляд» на лібералізацію рахунку капіталу, відповідно до якого лібералізація підходить не для всіх країн у будь-який час, і коли вона буде прийнята, то має бути поступовою та плановою (International Monetary Fund, 2012). Тому управління рахунками капіталу вважається інструментом політики за різних 
умов, як частина більш широкого пакету макропруденційних заходів та узгоджується із загальною макроекономічною політикою.

МВФ розпочав нову політику фінансування у 2009-2010-х рр., важливими елементами якої були: (1) створення умовної та превентивної кредитної лінії, Гнучка кредитна лінія (FCL), яка не відповідає умові ex ante; 2) дублювання інших кредитних ліній (включаючи найбільш традиційний резервний режим) та створення інших засобів профілактичного характеру для країн, які не відповідають вимогам щодо доступу до FCL; 3) більш широкий набір кредитних ліній для країн з низьким рівнем доходу; 4) нове правило, яке вказує на те, що виплати не можуть бути призупинені, якщо порушена будь-яка зі структурних умов, вони можуть бути зупинені за умови недотримання макроекономічних вимог. Однак останні умови повинні вважатися критично важливими для досягнення цілей угоди, дотримуючись принципів, прийнятих у 2002 р. після різкої критики передумов настання східноазіатської кризи.

Ключовим питання також $є$ те, як забезпечити ресурси, що їх МВФ має для фінансування своїх програм. Найбільш складним питанням було узгодження квот, які історично відставали від зростання світової економіки та, зокрема, потоків приватного капіталу. Переговори, що відбулися між 2006 і 2010 рр., призвели до подвоєння квот та помірного перерозподілу на користь країн, що розвиваються (3,9 \% квот). Однак ця угода набула чинності лише у 2016 р. через значні затримки з її затвердженням Конгресом США. Переговори про нову квоту, які мали відбутися в 2019 р., не вдалися через спротив Америки і до них повернуться лише в 2023 р. Тим часом ресурси, що надходять від країн до МВФ у рамках домовленостей про позики та різні двосторонні кредитні лінії механізм, який насправді не $є$ багатостороннім - будуть збережені.

Ще хотілося б наголосити, що нині не існує багатостороннього механізму перегляду державних боргів з приватними кредиторами, аніж фінансування платіжного балансу. Альтернатива цьому - заснування подібною до Паризького клубу установи, яка могла б розглядати борги з офіційними кредиторами. Тому переукладення державних боргів з приватними установами продовжує залежати від спеціальних механізмів з власниками облігацій або банкамикредиторами. Після втрати Аргентиною позовів у судах Нью-Йорка від кредиторів, які не брали участі у перегляді іноземних боргів у 2005 та 2010 рр., у 2014 р. була досягнута домовленість на рівні Правління МВФ та консенсус головної відповідної приватної асоціації (Міжнародної асоціації ринку капіталу) щодо запровадження нових пунктів випуску облігацій, які дозволять консолідувати борг й модифікувати так зване застереження pari passu, яке використовувалося кредиторами, що не брали участі в аргентинських переговорах, з метою подання позову проти цієї країни. ООН також затвердила деякі принципи реструктуризації державних боргів у 2015 р. 
Щодо цих питань, то порядок денний країн, що розвиваються, повинен включати стійкий захист макропруденційних норм для управління потоками капіталу - разом підтримкою МВФ, який може запропонувати більш амбіційні інструменти кредитування, і більш активне використання спеціальних прав запозичення як інструменту фінансування. Ключовим новим інструментом політики може бути механізм обміну, запропонований технічним персоналом МВФ у 2017 р. та групою експертів, скликаною G20 у 2018 р., а також шлях бі льш активного використання існуючих домовленостей. Додатковим елементом була б багатостороння установа для сприяння реструктуризації державних боргів 3 приватними кредиторами. Управління таким механізмом могло б здійснювати ООН або МВФ. Якщо МВФ є суб’єктом управління, тоді механізм повинен гарантувати повну незалежність відповідних арбітражних органів стосовно Ради Фонду.

Нарешті, все повинно супроводжуватися низкою інституційних реформ: заміна G20 на справді представницький глобальний орган; зміни в управлінні МВФ та Світовим банком, які розширюють участь країн, що розвиваються; i правила, які гарантують, що керівники цих організацій будуть проходити відбір, що грунтується винятково на достоїнствах кандидатів - чесний конкурс, в якому можуть брати участь громадяни з усіх країн.

\section{Висновки}

Підсумовуючи, важливо наголосити, що у 2015 р. ООН запустила три основні глобальні програми (Цілі сталого розвитку, Аддис-Абебська програма дій та Паризька кліматична угода), які виявилися істотним кроком вперед для світового співтовариства. Однак ця, можливо найамбітніша в історії, програма розвитку зіштовхнулася за останні роки з послабленням мультилатеральності, дестабілізацією та масштабними невизначеностями, що оточують світову економіку, до яких відтепер додалися наслідки пандемії COVID-19 для здоров'я, економіки та соціальної діяльності.

Очікуване сповільнення темпів зростання світової економіки погіршилося завдяки пандемії, яка породила найгіршу економічну кризу з часів Великої депресії. Міжнародна торгівля вже відчула на собі наслідки торгових війн та краху системи врегулювання суперечок у СОТ, а нині стикається 3 порушенням ланцюгів створення вартості. Також має місце найбільше скорочення 3 1930-х рр. Хоча наслідки, спричинені COVID-19 на фінансових ринках, пом'якшувалися масовим втручанням центральних банків розвинених країн, глобальна співпраця в цій галузі була набагато слабшою, ніж після Північно-Атлантичної фінансової кризи.

Щоб змінити та обернути у зворотному напрямку ці масові несприятливі тенденції, система ООН повинна постати форумом для великих політичних домовленостей, які мають важливе значення для досягнення амбіційних планів 
розвитку, погоджених у 2015 р. Ці глобальні політичні угоди повинні включати: по-перше, розроблення більш посилених механізмів співпраці з країнами, що розвиваються, не лише у сфері охорони здоров'я, а й для управління негативними соціально-економічними наслідками кризи COVID-19; по-друге, оновлення зобов'язань щодо зміцнення торговельної мультилатеральності та подолання поточного колапсу міжнародної торгівлі; по-третє, порядок денний для глобального валютно-фінансового співробітництва, не менш амбітний ніж той, що був прийнятий після північноатлантичної фінансової кризи. Аналіз цих ключових пунктів глобальної політичної угоди та вироблення на його основі конкретних практичних інструментів становлять перспективу подальшого розвитку досліджень у цьому напрямку.

\section{References:}

1. Bacchus, J., Lester, S. (2019). Of Precedent and Persuasion: The Crucial role of the Appeals Court in WTO Disputes. Free Trade Bulletin, no. 74 (12 September), pp. 1-6.

2. Bértola, L., Ocampo, J. A. (2012). The Economic Development of Latin America since Independence. Oxford: Oxford University Press,

3. Diao, X., McMillan, M., Rodrik, D. (2019). The recent growth boom in developing countries: a structural change perspective. The Palgrave Handbook of Development Economics: Critical Reflections on Globalisation and Development. Switzerland: Palgrave McMillan.

4. International Monetary Fund (2012). The liberation and management of capital flows: an institutional view. Washington, D.C. 14 November.

5. International Monetary Fund (2019). World Economic Outlook October 2019: Global Manufacturing Downturn, Rising Trade Barriers. Washington, D.C.: IMF.

6. International Monetary Fund (2020a). World Economic Outlook, April 2020: The Great Lockdown. Washington, D.C.:IMF.

7. International Monetary Fund (2020b). Global Financial Stability Report, April 2020. Washington, D.C.:IMF.

8. Kindleberger, Ch. (2011). Manias, Panics, and Crashes: A History of Financial Crises, 6th Ed. Houndmills, United Kingdom: Palgrave Macmillan.

9. Ocampo, J. A. (2017). Resetting the International Monetary (Non) System. Oxford: Oxford University Press and WIDER,

10. Reinhart, C., Rogoff, K. (2009). This Time is Different: Eight Centuries of Financial Folly. Princeton: Princeton University Press

11. World Bank. (2020). Commodities markets outlook: implications of COVID-19 for commodities. April. [online]. Available at: https://openknowledge.worldbank.org/bitstream/handle/10986/33624/CMOApril2020.pdf. 
Міжнародні відносини: теоретико-практичні аспекти

Випуск 6 (2020)

ISSN (print) 2616-745X; ISSN (online) 2616-7794

12. World Trade Organization. (2020). Trade set to plunge as COVID-19 pandemic upends global economy. 8 April. [online]. Available at: https://www.wto.org/english/news_e/pres20_e/pr855_e.htm.

(СРевенко А. Д., 2020 